\title{
APILAMÄTÄ APILAN TALVEHTIMISEN HEIKENTÄJÄNÄ SUOMESSA
}

\author{
Aarre YlimäkI \\ Kasvitautien tutkimuslaitos, Maatalouden tutkimuskeskus, Tikkurila
}

Saapunut 8. 7. 1969

Peltonurmien sadot pienenevät ja laatu heikkenee niiden iän lisääntyessä, joka johtuu lähinnä nurmien apilapitoisuuden vähentymisestä jo toisesta vuodesta lähtien. Apilan tuhouduttua valtaavat tavallisesti timotei ja muut heinät sekä rikkakasvit nopeasti sen tilan. Apiloiden osuus nurmissamme on nykyisin koko maassa keskimäärin noin $10 \%$, Etelä-Suomessa hieman runsaampi kuin muualla eli noin $13 \%$ (Mukula, Marttila ja RAatikainen 1968).

Syynä apilan häviämiseen nurmista on juurilahotauti (YLIMÄKI 1967) ja erilaiset talvehtimisvauriot, joista merkityksellisin on apilamätätauti. Se on ollut tunnettu apilaa ja muita nurmipalkokasveja tuhoavana kasvitautina jo yli sata vuotta, vaikka sen aiheuttaja, apilan pahkahomesieni Sclerotinia trifoliorum Erikss. selvitettiinkin vasta myöhemmin (ERIKsson 1880). Apilamädän aiheuttajina on toisinaan pidetty myös Mitrula sclerotiorum Rostr. ja Typhula trifolii Rostr.-sieniä, joita kuolleista apilan jätteistä on tavattu $S$. trifoliorumin ohella. Mitrula sclerotiorum on kuitenkin todettu viime aikoina suoritetuissa tutkimuksissa $S$. trifoliorumin eikä apilan loiseksi (RoED 1954, ZuB 1967, YLIмÄKI 1968) kun sitä vastoin sekä Typhula trifolii että $T$. ishikariensis Imai ovat apilan loisia (YLIMÄKI 1969).

Tässä tutkielmassa esitetään tietoja apilamätätaudin levinneisyydestä ja merkityksestä oloissamme sekä selostetaan eräitä apilan pahkahomeen biologiaa ja torjuntaa koskeneiden tutkimusten tuloksia.

\section{Levinneisyys ja vahingollisuus}

Apilan pahkahomeen levinneisyyttä ja vahingollisuutta maassamme ei ole aikaisemmin selvitetty, mutta tietoja apilamätätaudin paikallisista tuhoista on melkoisesti. VALLE (1935) piti apilan talvehtimista Tammiston kasvinjalostuslaitoksen olosuhteissa pääasiassa apilamädän esiintymisestä riippuvana, ja PoнJakallıo (1940) mainitsi taudin aiheuttaneen Jokioisissa 1930-luvulla pahoja tuhoja kaikkina muina talvina paitsi 1937/38 ja 


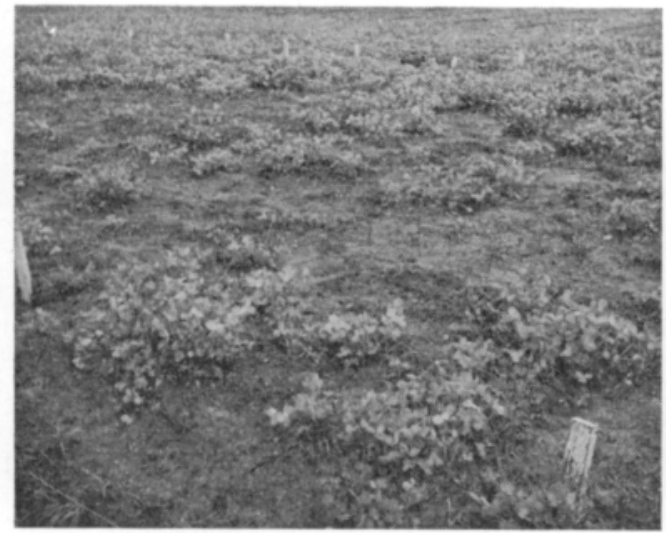

Kuva 1. Apilamädän aiheuttamaa tuhoa lajikekokeissa Pohjois-Pohjanmaan koeasemalla Ruukissa keväällä 1952 .

Fig. 1. Damage caused by clover rot in variety trials in North Ostrobothnia Agr. Exp. Sta., Ruukki, Spring 1952.

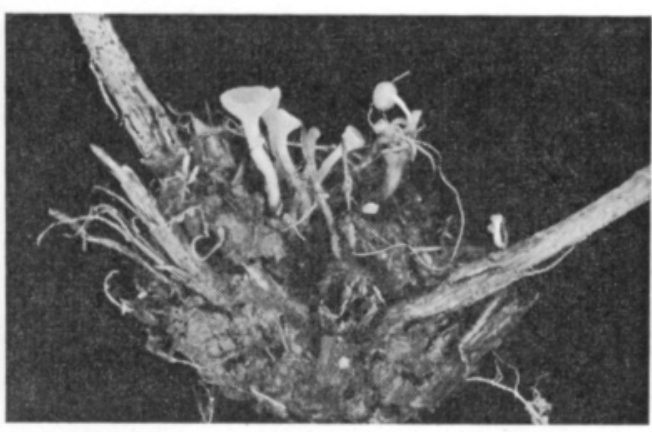

Kuva 2. Apilan pahkahomeen kotelomaljoja. Fig. 2. Apothecia of $S$. trifoliorum.

1939/40. Taudin haitallista vaikutusta apilan säilymiseen ovat painottaneet myös mm. Salminen (1950), Köyljürvi (1959), YlimäKi (1955) ja Jamalainen (1958). Viimeksi mainitun mukaan apilamätä on apilan häviämisen pääasiallisena syynä etelä- ja keskiosissa maata 5-8 talvena 12:sta. Merkillepantavaa on, ettei apilamädällä ole TakaLapissa samaa merkitystä kuin etelämpänä koska kesä muuttuu siellä talveksi niin nopeasti, ettei apilamätäepidemia ehdi puhjeta (Pohjakallio ja Salonen 1959).

Apilamädän levinneisyystiedot sieninäytteineen on kerätty pääasiassa vuodesta 1946 lähtien eri tahoille maata tehdyillä matkoilla. Lisäksi on toimeenpantu kirjeellisiä tiedusteluja, joissa viljelijöiltä on pyydetty tietoja apilan viihtyvyydestä heidän viljelyksillään sekä heidän käsityksiään apilan häviämisen tärkeimmistä syistä. Sekä apilan talvehtimistiedustelujen vastaukset että kirjoittajan matkoilla tekemät havainnot osoittavat, että apilan talvehtimiseen haitallisesti vaikuttavien tekijöiden erottaminen toisistaan on siksi vaikeata, etteivät tiedustelut anna luotettavaa kuvaa niiden merkityksestä. Apilamätä on verraten heikosti tunnettu tauti, joten sen aiheuttamat tuhot otaksutaan usein talven haitallisten sääolojen aiheuttamiksi ja toisinaan päinvastoin. Asiaa vaikeuttaa vielä apilan juurilaho, joka ei silmävaraisesti ole hevin tunnistettavissa.

Kirjoittaja on useiden vuosien aikana kerännyt ja puhtaaksi viljellyt $S$. trifoliorum aineistoa kaikkiaan 91 kunnan alueelta yhteensä 392 näytettä (kuva 3). Vaikka aineisto ei peitäkään maatamme kokonaan, osoittaa se kuitenkin selvästi, että sieni on levinnyt maassamme koko tärkeimmälle apilan viljelyalueelle. Tässä yhteydessä voitiin panna merkille, että rannikkoalueilla, jotka ilmastollisesti poikkeavat niukkalumisuutensa vuoksi maan muista osista (vrt. YLIMÄKI 1962), tavattiin apilan pahkahometta vähemmän kuin muualla maassa. Mitä tulee apilamätätaudin vahingollisuuteen, kuvastavat sitä parhaiten jäljempänä esitettävät torjuntakokeiden tulokset (taul. 4 ja 5). 


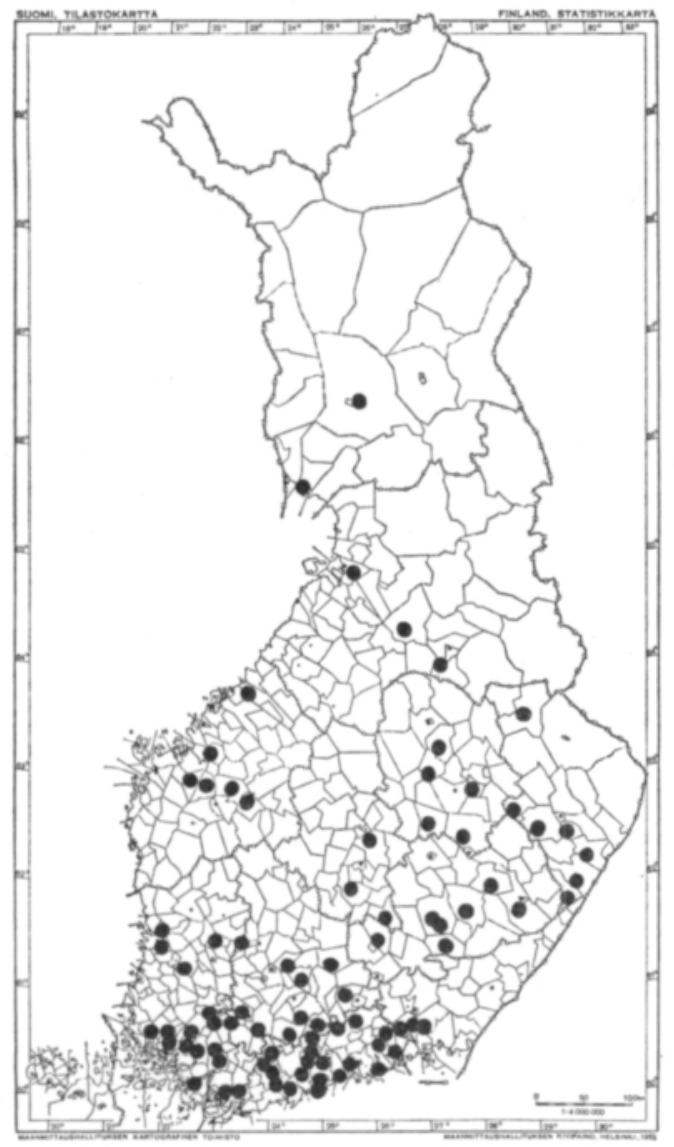

Kuva 3. Apilamätänäytteiden löytöpaikkakunnat.

Fig. 3. The communes in which the $S$, $t$ if o l $i$ or $u m$ samples originated.

\section{Esiintymisen edellytykset}

Käsitykset apilan pahkahomeen pääasiallisesta saastutus- ja leviämistavasta vaihtelevat kirjallisuuden mukaan melkoisesti. Yleisin käsitys on, että ainakin primäärisen saastunnan aiheuttavat isäntäkasvien lehdille syksyllä joutuneet koteloitiöt (BJöRLING 1951, LOveLEss 1951). Kotelomaljat kehittyvät rihmastopahkoista oloissamme tavallisesti syksyllä. Osoituksen siitä, että niitä voi kehittyä luonnon oloissa myös muulloin, kirjoittaja sai tavattuaan syksyllä ulos maan pinnalle asettamissaan rihmastopahkoissa täysin fertiilejä kotelomaljoja seuraavana keväänä toukokuussa (vrt. VAlleau, Fergus ja Henson 1933, s. 241). Rihmastopahkoista kasvaneen rihmaston on myös todettu voivan aikaansaada taudin valtaan pääsyn olosuhteissa, joissa ei itiöemiä ole tavattu lainkaan tai vain nimeksi (FrandSEN 1946, YLIMÄKI 1956). Sienen kaukoleviäminen voi tapahtua apilan siemenen mukana etenkin rihmastopahkojen välityksellä (LEAcH 1958).

Muiden talvituhosienien tavoin apilamädän iskeytyminen kasveihin alkaa jo syksyllä ja jatkuu koko talven ajan. Apilamädän tuhot voivat tulla jo syksyllä selvästi havaittaviksi, jos syyskauden sääolot ovat sille suotuisat. Taulukkoihin $1-2$ on kerätty säätiedot sekä muistiinpanot apilan talvehtimisesta Tikkurilassa 20 vuoden ajalta.

Apilamädän valtaan pääsy näyttää olevan riippuvainen ensi sijaisesti syyskauden 


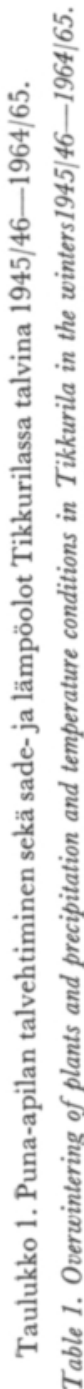

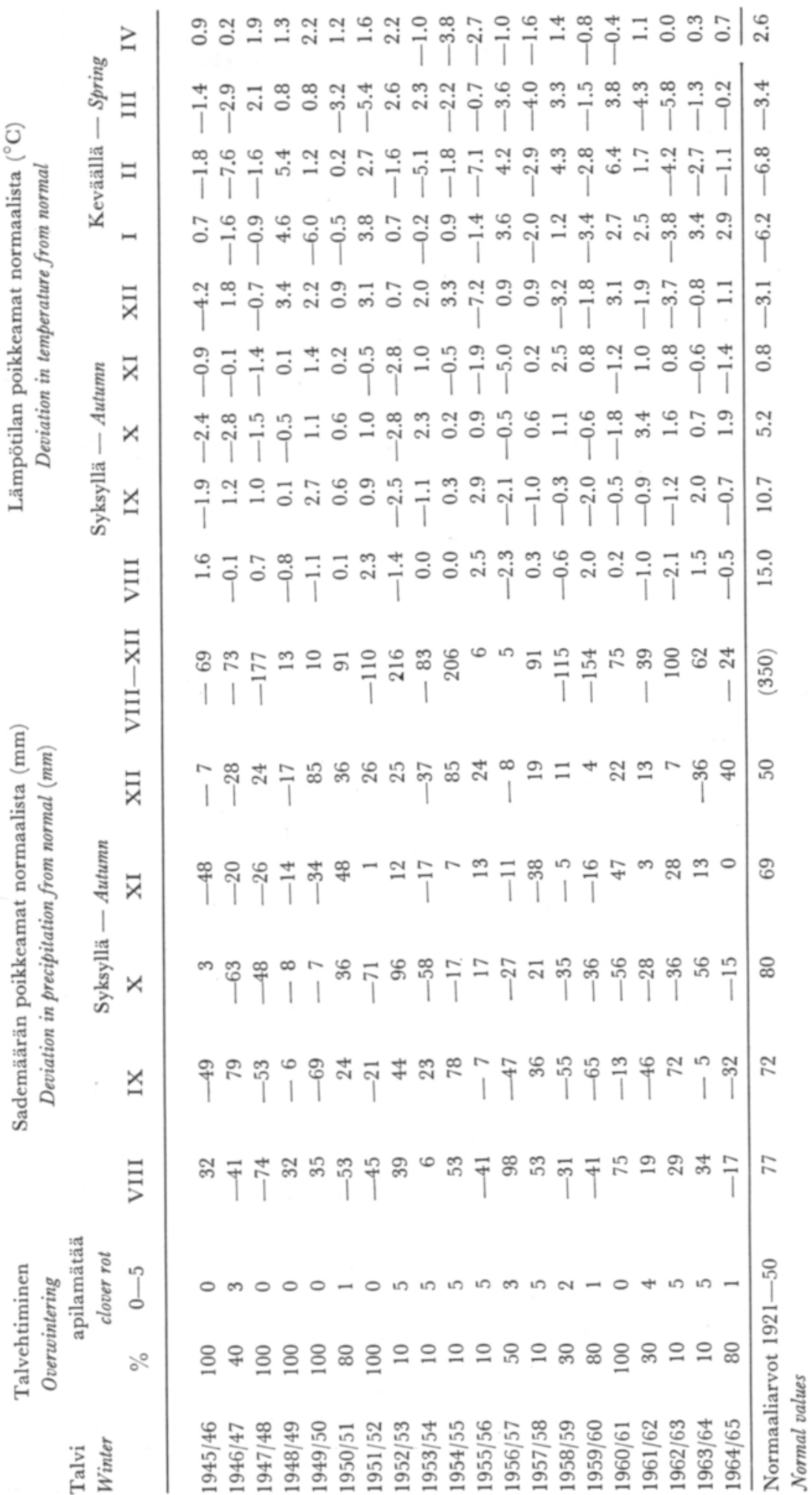




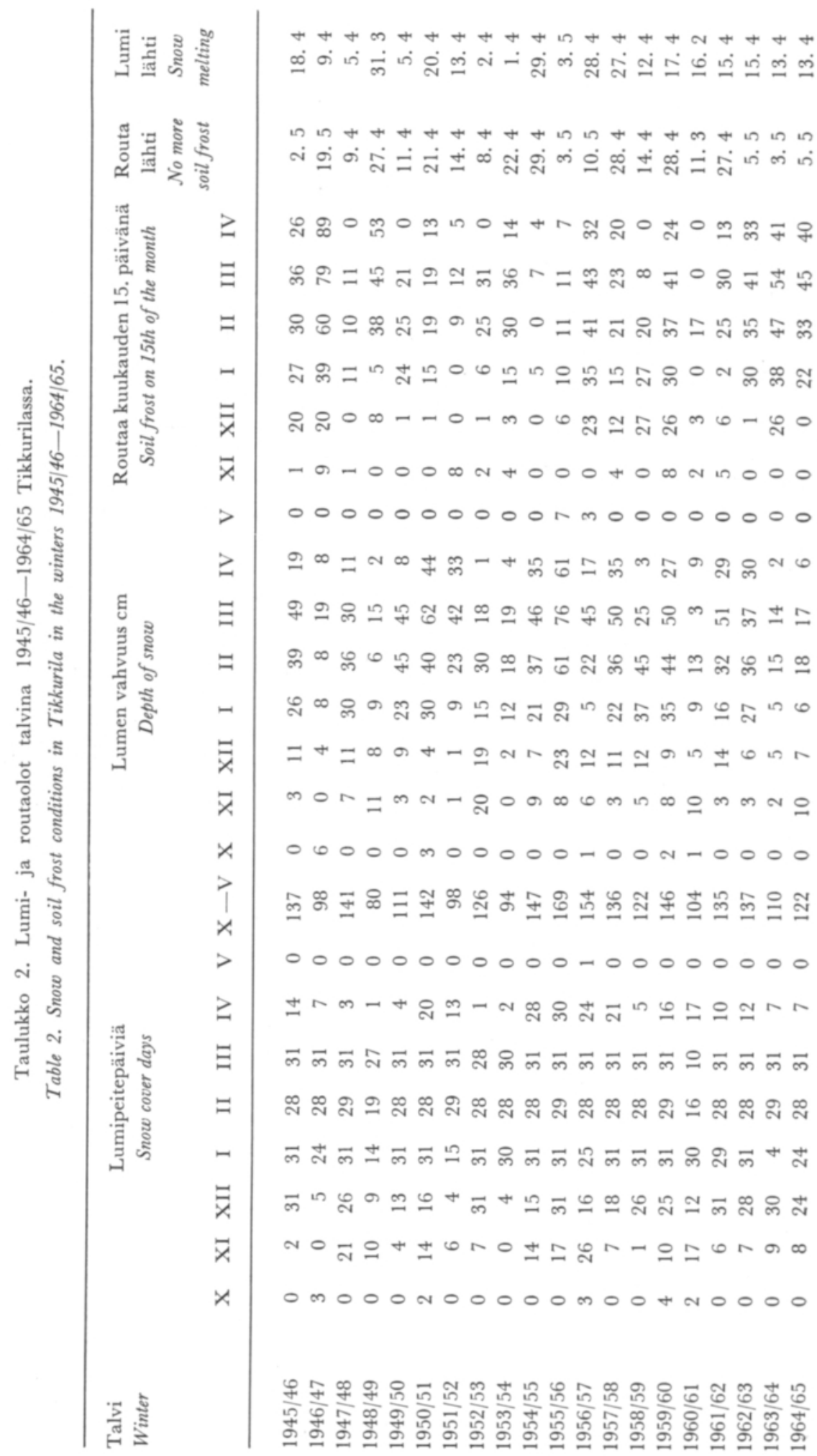


kosteudesta ja sateisuudesta (vrt. Bingefors 1951). Lämpötilan merkitys on ilmeisesti. vähäisempi; pakkassäät kuitenkin pysähdyttävät epidemian, koska silloin ilman suhteellinen kosteus laskee. Lämpötilaan nähden $S$. trifoliorum on varsin mukautuvainen: rihmaston kasvun optimilämpötila on $15-20^{\circ} \mathrm{C}$, maksimi $25-33^{\circ} \mathrm{C}$ ja minimi $0-5{ }^{\circ} \mathrm{C}$ : (PApe 1937, Kreitlow ja Spraque 1951).

Kotelomaljojen kehittymiselle otollinen lämpötila-alue on niinikään varsin laaja, $5-20^{\circ} \mathrm{C}$. Pellolla on apilan pahkahomeen todettu usein leviävän ja iskeytyvän apiloihin erittäin tehokkaasti optimilämpötiloja alhaisempien lämpötilojen vallitessa. Tämä johtuu siitä, että pellolla vallitsevat tällöin samanaikaisesti useat tälle sienelle ja epidemian syntymiselle suotuisat tekijät eli nimenomaan ilman korkea suhteellinen kosteus ja sieniaineiston runsaus.

Apilan pahkahome ei siis suosi alhaisia lämpötiloja, mutta se voi sietää niitä ja käyttää hyväkseen syksyisin vallitsevaa ilman suurta kosteutta, joka sienelle on välttämätön (vrt. BJöRLING 1951). Kosteutta on apilakasvuston peittämän maan pinnan läheisessä ilmakerroksessa syksyisin yleensä sienelle riittävästi ilman suhteellisen kosteuden ollessa yleensä $80-90 \%$. Sen sijaan kuivat säät voivat pysähdyttää jo alkuun päässeen sienen leviämisen niinkuin mm. Pohjakallio (1939) on todennut. Kun maan routaantuminen. syksyllä ennen pysyvän lumen tuloa vaikuttaa kuivattavasti, on se omiaan rajoittamaan S. trifoliorumin leviämismahdollisuuksia sekä syksyllä että myöhemminkin lumen alla. Sen sijaan sulaan maahan sataneen lumipeitteen alle muodostuu sienelle kosteuden kannalta mitä suotuisimmat olot. Silloin kun lumipeite on siksi vahva, että se eristää maan pinnan ulkoisilta sään vaihteluilta, pysyttelee lämpötila lumen alla 0-asteen vaiheilla (YLIMÄKI 1962). Veden tai jään peittämässä maassa eivät sienet voi tulla toimeen pitkiä aikoja, koska ne tarvitsevat elintoimintoihinsa happea isäntäkasviensa tavoin.

Talven sääoloilla ei apilamädän esiintymiseen ole yhtä suurta vaikutusta kuin niillä on syysviljojen talvehtimiseen. Kuitenkin on voitu panna merkille, että pitkään viipyvän ja runsaan lumipeitteen hidas sulaminen on omiaan edistämään apilamädän tuhojen jatkumista keväällä, koska se pitää maan pinnan kosteana. Tällaisen poikkeuksellisen voimakkaan keväisen apilamätäepidemian vuoksi tuhoutui esim. alkukesällä 1967 Tikkurilassa alsikeapilan siemenviljelys kokonaan.

Keväällä kun lumi on sulanut, muuttuu mikroilmasto yleensä nopeasti pahkahomeelle liian kuivaksi, joten keväällä ja vielä vähemmän kesällä ei apilamädän tuhoja tavallisesti tapahdu. Toisinaan tauti saattaa kuitenkin päästä valtaan kesälläkin. Näin kirjoittaja havaitsi tapahtuvan mm. vuonna 1948, jolloin apilamätä alkoi levitä apilan lajikekokeessa Tikkurilassa keskikesällä, heinäkuussa. Tätä edelsi pari vuorokautta jatkunut, melko hiljainen sade ja ilman korkea suhteellinen kosteus.

Vaikka apilamädän puhkeaminen on suuresti riippuvainen syyskauden sääoloista, on taudin esiintymisessä havaittavissa myös vaihtelua, jota ei voida pitää sääoloista suoranaisesti riippuvana. Onko tällöin kysymys rihmastopahkojen säilyvyydestä (HALKILAHTI 1962) vaiko maassa olevien apilan pahkahomeen kasvua estävien pieneliöiden vaikutuksista (PohjaKallio 1959, Halкilahti 1964), on vaikeata varmuudella päätellä.

Sillä miten elinvoimaisessa kunnossa apila jää syksyllä talvehtimaan, on ilmeisesti suurempi merkitys kuin on luultu. Näin on laita ennen kaikkea ensi kertaa talvehtimaan joutuvissa nuorissa apilataimistoissa. Apilan lehdistön liiallinen rehevyys voi toisinaan muodostua apilamädän tuhoja lisääväksi tekijäksi. Voi olla tarpeen säännöstellä tai- 
miston rehevyyttä niittämällä. Kun kuitenkin niiton jälkeen kasvanut odelma on erittäin altis apilamädälle, on apilan ennätettävä niiton jälkeen riittävästi voimistua ennen kuin taudin iskeytyminen kasveihin tapahtuu. On todettu, että elo-syyskuun vaihteessa pitkään sänkeen suoritettu niitto lieventää apilamädän tuhoja kun taas myöhäisempi, maata myöten tehty niitto alentaa taudinkestävyyttä (vrt. TerTtrinen 1959).

\section{Sienen patogeenisuus}

Matkoilla tehtyjen havaintojen mukaan apilamädän esiintymisvoimakkuudessa on paikallisia eroja siten, että tauti joillakin paikoin aiheuttaa useimpina vuosina suuria tuhoja ja kaikkinakin vuosina ainakin lievää vahinkoa. Toisin paikoin tuhoja on vain

Taulukko 3. Apilan pahkahomeisolaattien patogeenisuus

Table 3. Pathogenicity of isolates of Sclerotinia trifoliorum.

Lavakoe Tammiston puna-apilalla.

Trial in bed, Tammisto red clover.

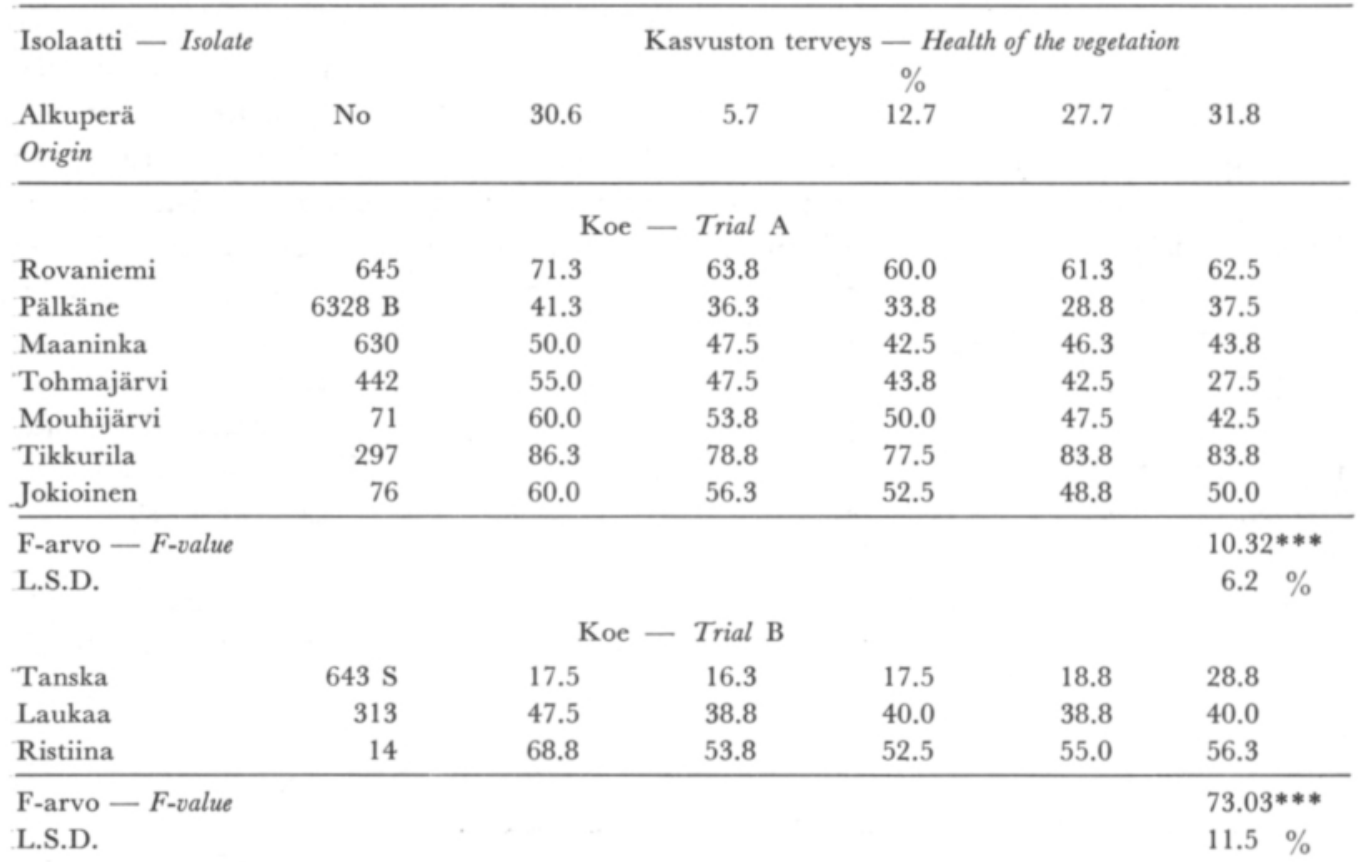

hyvin harvoin ja silloinkin useimmiten vain lieviä. Eräiden tällaisten havaintopisteiden $S$. trifoliorum-isolaattien patogeenisuutta verrattiin lavakokeissa. Höyryttämällä desinfioitu multa inokuloitiin ennen apilan kylvöä Rhizobium-bakteereilla.

Kokeet osoittivat, että eri alkuperää olleiden isolaattien patogeenisuudessa oli merkitseviä eroja (kuva 4 ja taul. 3). On ilmeistä, että kysymys on $S$. trifoliorum-sienen biotyypeistä tai patogeenisista roduista, jollaisia PoHJAkallio (1939) on todennut maassamme esiintyvän. Apilan taudinkestävyysjalostuksen kannalta biotyyppien tai rotujen 


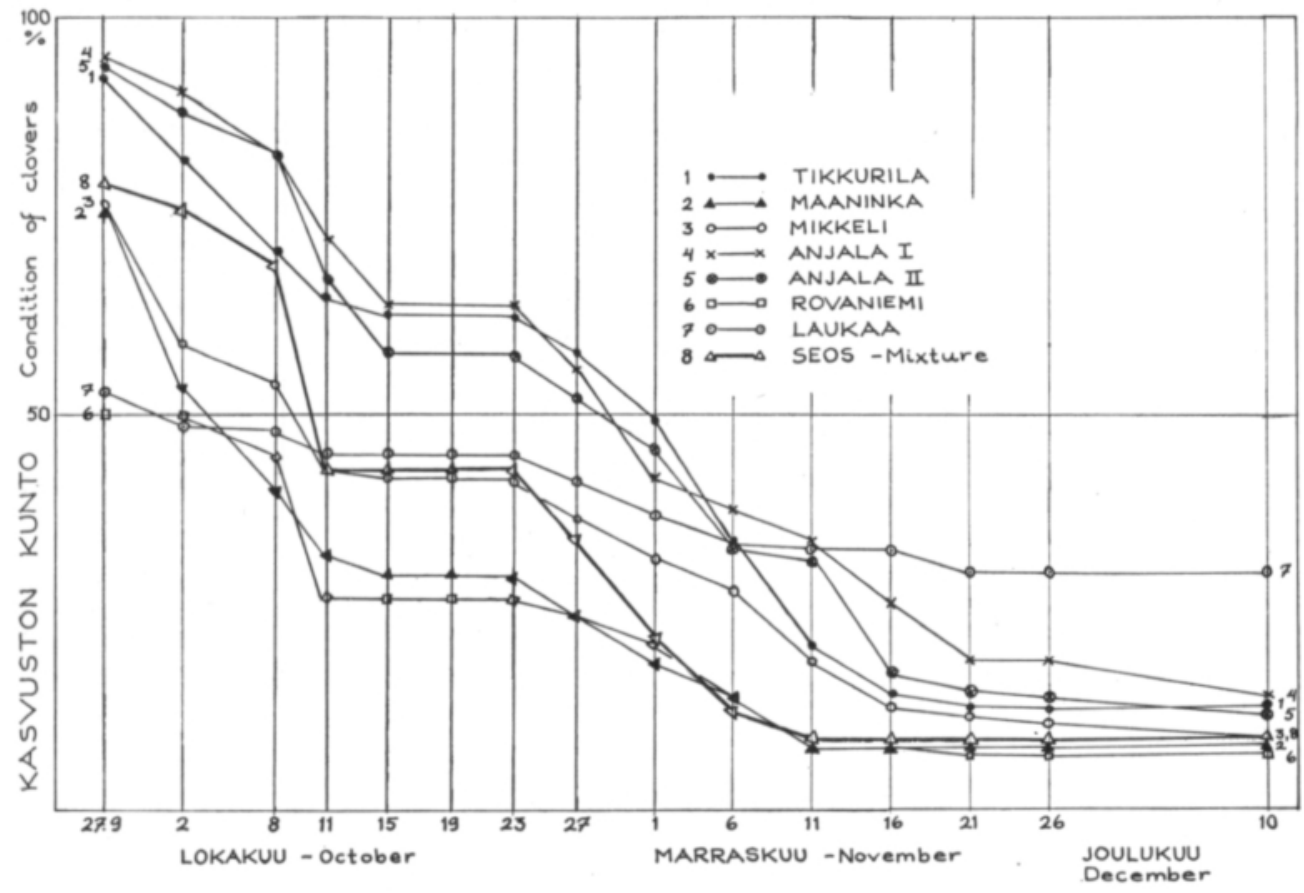

Kuva 4. Eri alkuperää olevien pahkahome-isolaattien patogeenisuus.

Fig. 4. The pathogenicity of Sclerotinia isolations of different origins.

toteaminen on erittäin merkittävää, koska se osoittaa, että jalosteiden testaus on suoritettava useita paikkakuntia edustavalla $S$. trifoliorum-aineistolla (vrt. kuva 4). Eräät tutkimukset osoittavat, ettei monien isolaattien seoksella saada yhtä hyvää testaustulosta kuin kullakin seoksen osa-isolaatilla erikseen (BEHRINGER 1963), mutta tarkoituksenmukaista lienee sittenkin käyttää seosta.

Edellä mainituissa kokeissa voitiin todeta isolaattien aiheuttamien tuhojen välisten erojen yhä pienenevän syksyn kuluessa, koska hitaammin tuhoa tekevät isolaatit saavuttivat nopeammat (kuva 4). Patogeenisuuden voimakkuus näytti siis olevan ajan funktio, niinkuin Pohjakallio (1940) arveli olevan.

\section{Taudinkestäryys}

Taudinkestävien lajikkeiden viljely olisi paras apilamädän torjuntakeino. Apilan jalostustyössä onkin apilamädänkestävyyden parantaminen eräs tärkeimpiä tavoitteita. Taudinkestävyyttä ei apilamätään nähden tiettävästi ole saavutettu todellisena resistenssinä, vaan perustuvat saavutetut kestävyyserot ns. näennäiseen taudinkestävyyteen, joka on riippuvainen ympäristötekijöistä enemmän kuin itse kasvin luontaisesta valmiudesta kestää taudin hyökkäykset. Apilajalosteiden tai -kantojen kestävyyserot perustuvat itse asiassa niiden kykyyn viivyttää taudin valtaan pääsyä (kuva 5). Pitkänä syksynä ja leutona talvena ehtii apilamätä saastuttaa pahoin normaalioloissa verraten kestävätkin apilat. 
Ekologisella sopeutumisella on hyvin suuri vaikutus apilan viihtymiseen. Maassamme on paljon paikallisia puna-apilakantoja, joita on samalla tilalla viljelty menestyksellisesti vuosikymmeniä. Ne edustavat arvokasta, pitkäaikaisen sopeutumisen tuloksena syntynyttä aineistoa, jolla kuitenkin on sellaisenaan merkitystä vain viljelypaikallaan. Jalostusaineistona tällaiset apilat voisivat olla kuitenkin varsin arvokkaita niinkuin mm. CARR (1954) toteaa. Kirjoittaja on havainnut tällaisten apiloiden toisiin oloihin vietynä tuhoutuvan pahoin apilamädän takia (vrt. taul. 8, 10). Tällaisissa tapauksissa voi olla kysymys joko siitä, että apilat ovat varsinaisen viljelyalueensa ulkopuolella alttiimpia taudille tai sitten erilaisen patogeenisuuden omaavien sienirotujen olemassaolosta.

\section{Torjunta kemikaaleilla}

Kasvitautien tutkimuslaitoksella ryhdyttiin v. 1946 tutkimaan apilamädän ja muidenkin talvituhosienien torjuntamahdollisuuksia PCNB-valmisteilla sekä myös lukuisilla muilla kemikaaleilla (YLIMÄKı 1969 b). Alustavia tietoja näiden tutkimusten tuloksista on jo aikaisemmin julkaistu (YLıмÄкı 1955, 1956). Tässä julkaisussa esitetään yhdistelmä kaikista vuosina 1946 - 65 suoritetuista torjuntakokeista ja niihin liittyneistä muista tutkimuksista.

Suurin osa kenttäkokeista on suoritettu Maatalouden tutkimuskeskuksessa Tikkurilassa ja Etelä-Pohjanmaan, Etelä-Savon, Hämeen, Karjalan, Keski-Pohjanmaan, Keski-Suomen, Lounais-Suomen, Perä-Pohjolan, Pohjois-Pohjanmaan, Pohjois-Savon, Satakunnan sekä Laidunkoeasemalla. Muutamia kokeita on lisäksi järjestetty yksityisillä maatiloilla. Torjuntakokeiden yhteydessä on pyritty selvittämään apilamätätaudin osuutta apilan talvehtimisvaurioissa nurmissamme yleensä ja myös sen merkitystä apilalajikkeiden talvenkestävyydessä. Kenttäkokeet suoritettiin joko lohkomenetelmää tai latinalaista suorakulmiomenetelmää käyttäen ja on niissä ollut kerranteita 4 tai 6 koeruutujen koon vaihdellessa enimmäkseen $10-25 \mathrm{~m}^{2}: \mathrm{n}$ välillä. Tikkurilan kokeissa pölytteet levitettiin ko. tarkoitusta varten valmistetulla työnnettävällä laitteella (YLIMÄKı 1955 s. 148) muualla erilaisilla lietso- tai paljepölyttimillä. Ruiskutteiden levitys suoritettiin joko reppuruiskulla tai moottoriselkäruiskulla. Tuulen haitallinen vaikutus pyrittiin eliminoimaan tavallisesti ruutujen välisin suojakaistoin ja toisinaan kovalevystä valmistettua $70 \mathrm{~cm}$ :n korkuista siirrettävää tuulensuojaa käyttäen. Koealojen kasvustojen tiheydestä tehtiin havainnot sekä syksyllä ennen käsittelyjen aloittamista että keväällä heti kun lumi oli sulanut ja toistamiseen noin 2 viikon kuluttua. Tiheyden arvostelemiseen käytettiin prosenttiasteikkoa, jossa 100 merkitsee täysin tiheätä ja 0 kokonaan tuhoutunutta kasvustoa. Kasvien talveh-

timinen on laskettu kaavasta $T=100 \times \frac{\text { tiheys keväällä }}{\text { tiheys syksyllä }}$

Kun apilamädän erilaisesta esiintymisvoimakkuudesta johtuen torjuntakokeiden tulokset vuosittain ja koepaikoittain vaihtelivat erittäin paljon, on koesarjojen tulosten testaamisessa käytetty koejäsenten parittaisia erotuksia ja näille laskettuja keskivirheitä (erotusanalyysi). Erojen merkitsevyyttä on tarkasteltu t-arvoa käyttäen.

Kokeiden tulosaineistossa on joukko sellaisia tapauksia, joissa käsittelyt jäivät heikkotehoisiksi tai kokonaan tehottomiksi apilamädän niukan esiintymisen taikka myös torjuntakäsittelyn sopimattoman suoritusajan tai -tavan vuoksi. Siitä huolimatta tulokset osoitta- 


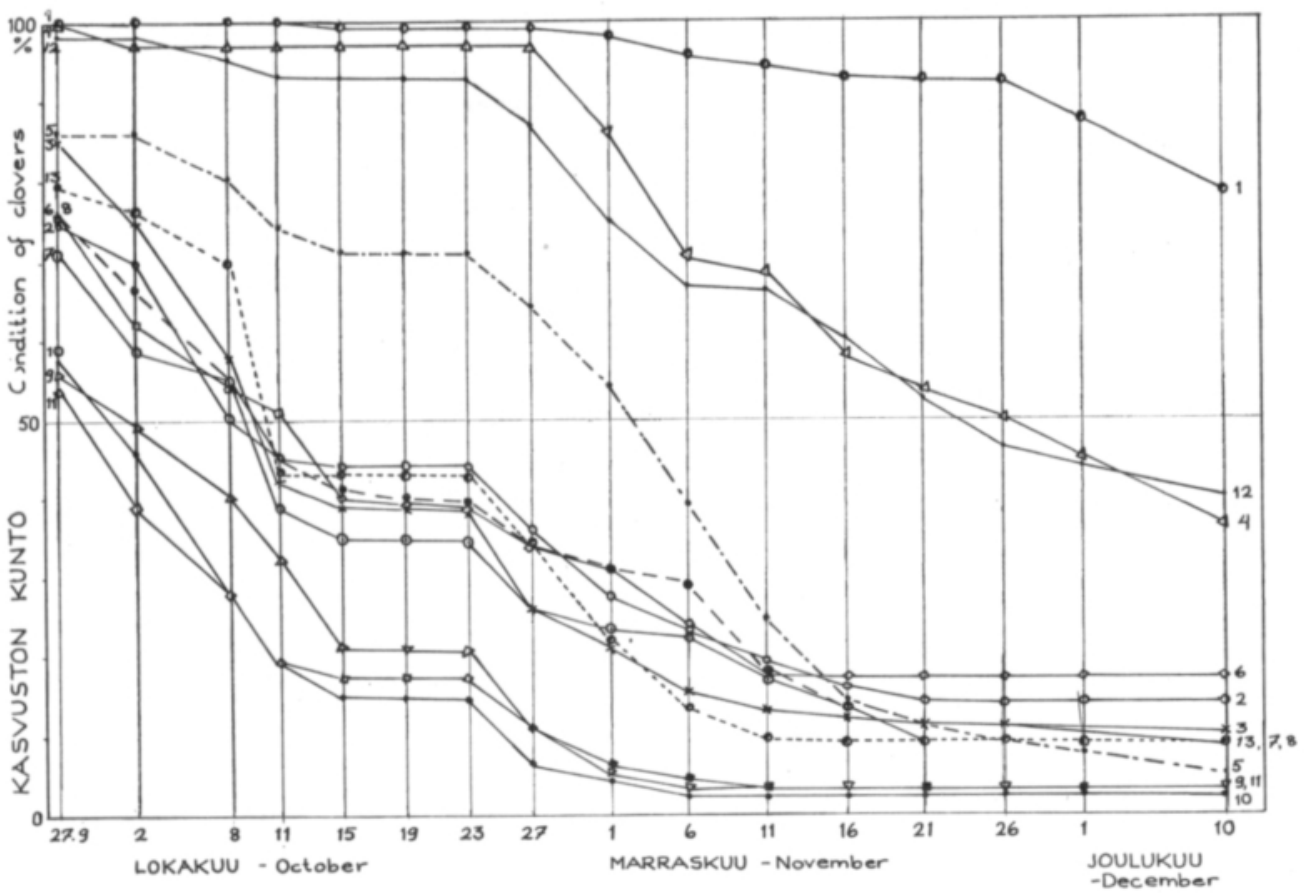

Kuva 5. Puna-apilalajikkeiden apilamädänalttius. Lajikkeet $2-13$ inokuloitiin samalla pahkahomeisolaattien seoksella, mitä käytettiin kuvassa 4 esitetyssä patogeenisuuskokeessa. 1. Tammisto, ei inokuloitu — no inoculation, 2. Jokioinen, 3. Tepa (4 n), 4. Ottawa, 5. Lasalle, 6. Ulva (4 n), 7. Myttäälä, 8. Olanda, 9. Hakanen, 10. Haapaniemi, 11. Tyhtilä, 12. Ylitalo, 13. Tammisto.

Fig. 5. Susceptibility to clover rot of red clover varieties. Varieties 2-13 were inoculated with mixture of $S$. $t r i f$ oli or $u m$ isolates used in pathogenicity test presented in Fig. 4.

vat, että apilapitoisten nurmien PCNB-käsittelyistä on oloissamme saatavissa huomattavan suuret sadonlisäykset. Kahdelta niittokerralta on kaikkien käsittelyjen (145) tuottama tuoreen sadon lisäys ollut keskimäärin $41 \%$, suurimman sadonlisäyksen oltua $379 \%$. Yhden niittokerran tuottama heinäsadon lisäys kaikista käsittelyistä (186) on ollut keskimäärin $26 \%$ ja parhaassa tapauksessa $365 \%$ (Taulukko 4). Kaikista käsittelyistä on lähes puolet tuottanut kahdelta niittokerralta vähintään $21 \%$ suuruisen tuoreen sadon lisäyksen ja vajaa neljännes vähintään $21 \%$ suuruisen heinäsadon lisäyksen yhdeltä niittokerralta (taulukko 5).

Koetulokset osoittavat, niinkuin oli odotettavissa, että torjunnan ajankohdalla on ratkaiseva vaikutus torjunnan onnistumiseen. Torjuntakäsittely on suoritettava ennen kuin tauti pääsee valtaan. Torjunnan ajankohta on valittava syyskauden kosteusoloja seuraten, koska apilamädän puhkeaminen ja leviäminen voivat tapahtua vain kasvillisuuskerroksen ilmaston suhteellisen kosteuden ollessa korkea. Joskus alkusyksyn ollessa vähäsateinen on kokeissa riittänyt yksikin loka- tai marraskuussa suoritettu torjuntakäsittely, mutta varmempi tulos on saavutettu kahdella tai kolmella syksyn aikana toimitetulla käsittelyllä. Näin on välttämätöntä menetellä varsinkin silloin kun syyskausi on sateinen ja apilakasvusto erittäin rehevä. Samankaltaisen käsityksen ovat esittäneet myös MALmus (1957) ja ZoGg (1957).

Riittäväksi tehoaineen, PCNB:n, määräksi on osoittautunut $5-6 \mathrm{~kg} / \mathrm{ha}$ edellyttäen, että 


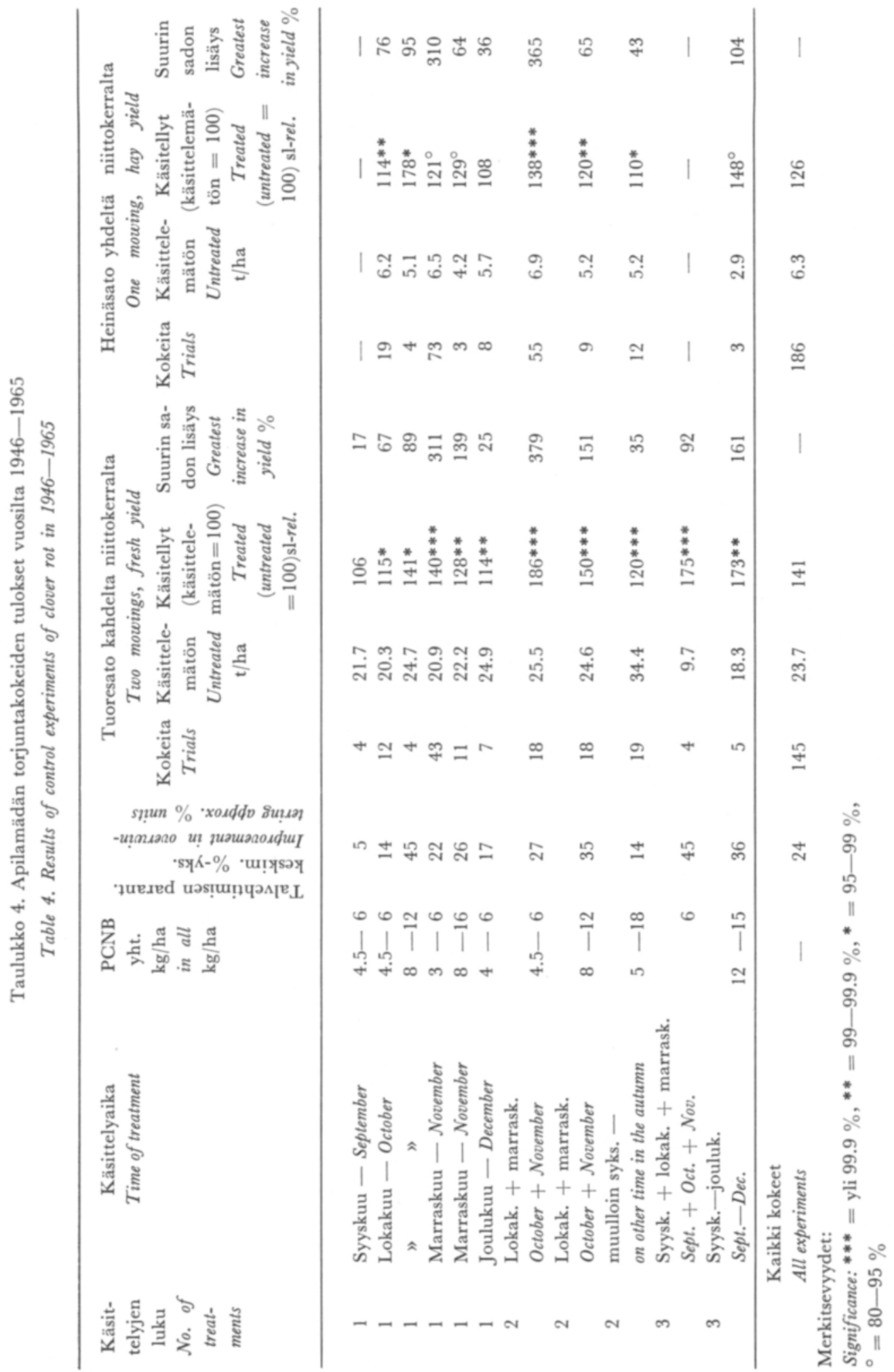




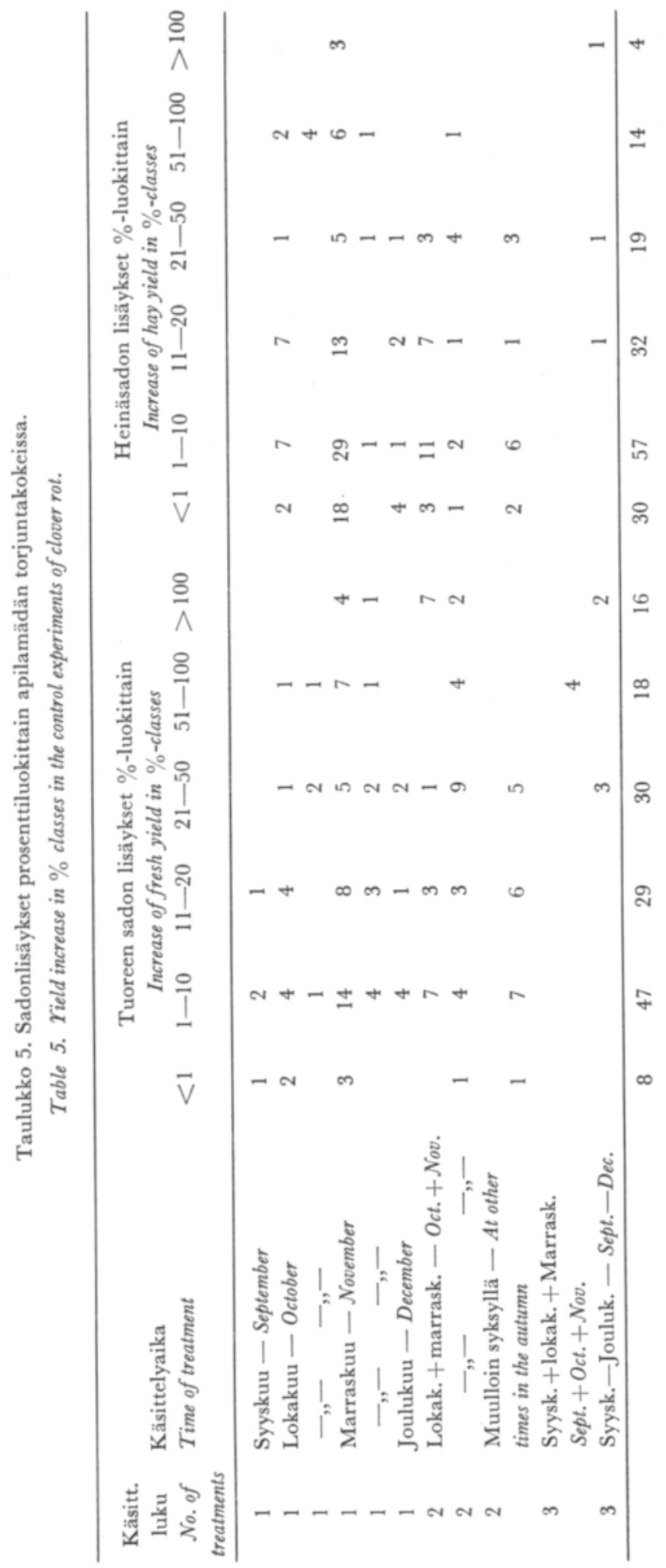




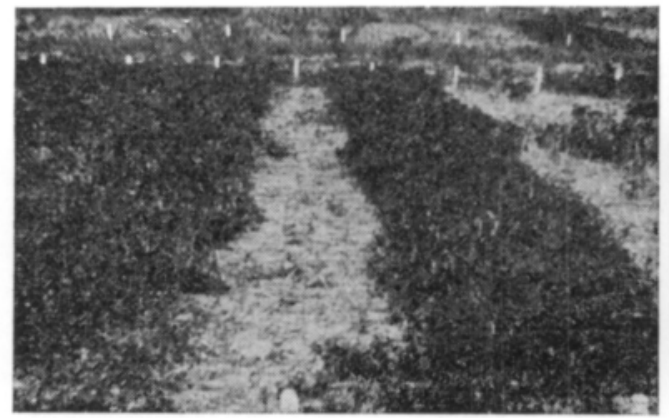

19.11 .
21.10.

A

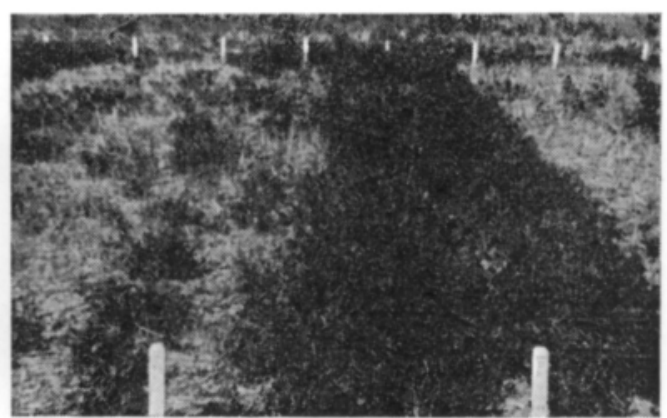

21.10.

10.11 .

B

Kuva 6. Käsittelyaika-ainemääräkoe talvella 1955/56. A 4 kg/ha B 8 kg/ha. PCNB.

Fig. 6. Experiment on time and amount of the treatment in winter 1955/56; A $4 \mathrm{~kg} / \mathrm{ha}, \mathrm{B} 8 \mathrm{~kg} / \mathrm{ha} \mathrm{PCNB}$.

Taulukko 6. PCNB-pölytteen ja ruiskutteen vertailu. Table 6. Comparison of PCNB dust and spray.

Käsittelyajat - Times of treatment: $9.9,7.10,6.11$

\begin{tabular}{|c|c|c|c|c|c|c|c|c|}
\hline \multirow{3}{*}{$\begin{array}{l}\text { Valmiste } \\
\text { Preparation }\end{array}$} & \multirow{3}{*}{$\begin{array}{c}\text { Teho- } \\
\text { ainetta } \\
\text { yht. } \\
\text { Effective } \\
\text { material, } \\
\text { total } \\
\mathrm{kg} / \mathrm{ha}\end{array}$} & \multirow{3}{*}{$\begin{array}{c}\text { Talvehti- } \\
\text { minen } \\
\text { Over- } \\
\text { wintering } \\
\%\end{array}$} & \multicolumn{6}{|c|}{ Tuoresato - Fresh yield } \\
\hline & & & \multicolumn{2}{|c|}{$\begin{array}{l}\text { 1. niitto } \\
\text { 1st mowing }\end{array}$} & \multicolumn{2}{|c|}{$\begin{array}{l}\text { 2. niitto } \\
\text { 2nd mowing }\end{array}$} & \multicolumn{2}{|c|}{$\begin{array}{c}\text { Yhteensä } \\
\text { Totally }\end{array}$} \\
\hline & & & t/ha & $\begin{array}{l}\text { sl. } \\
\text { rel. }\end{array}$ & $\mathrm{t} / \mathrm{ha}$ & $\begin{array}{l}\text { sl. } \\
\text { rel. }\end{array}$ & t/ha & $\begin{array}{l}\text { sl. } \\
\text { rel. }\end{array}$ \\
\hline Käsittelemätön - Control & - & 21.9 & 3.5 & 33 & 7.1 & 67 & 10.6 & 100 \\
\hline Avicol pölyte - dust & 6 & 53.8 & 5.4 & 51 & 9.4 & 89 & 14.8 & 140 \\
\hline Avicol ruiskutejauhe $-w p$. & 6 & 63.9 & 6.7 & 63 & 10.8 & 102 & 17.5 & 165 \\
\hline Brassicol $\quad, \quad-w p$. & 6 & 72.6 & 7.6 & 71 & 9.2 & 87 & 16.8 & 158 \\
\hline Fartox $\quad,, \quad-w p$. & 6 & 75.2 & 7.6 & 71 & 11.0 & 104 & 18.6 & 175 \\
\hline Avicol pölyte - dust & 12 & 90.6 & 10.3 & 97 & 12.3 & 116 & 22.6 & 213 \\
\hline Avicol ruiskutejauhe $-w p$ & 12 & 99.0 & 13.1 & 124 & 12.1 & 114 & 25.2 & 238 \\
\hline $\begin{array}{l}\text { F-arvo }-F \text {-value } \\
\text { L.S.D. }\end{array}$ & & & & & & & & $\begin{array}{l}6.05^{*} \\
3.9 \mathrm{t}\end{array}$ \\
\hline
\end{tabular}

aine saadaan levitetyksi nurmelle tasaisesti. Aineen määrän lisääminen tästä voi toisinaan antaa täydellisemmän torjuntatuloksen, mutta ero on tavallisesti siksi vähäinen, ettei se vastaa kustannusten lisäystä, niinkuin nähdään taulukossa 6 esitetystä ainemääräkokeesta. Samasta kokeesta ilmenee myös, ettei PCNB-valmisteiden käyttömuodolla ole kovin suurta merkitystä, jos mitään, torjunnan tulokseen. On kuitenkin syytä ottaa huomioon, että ruiskutteena on aineiden tasainen levittäminen helpompaa kuin pölytteenä, jolla seikalla tietysti on suuri vaikutus torjunnan onnistumiseen. Ruiskutteen levittäminen voidaan toimittaa myös paljon epäedullisemmissa sääoloissa kuin pölytteiden. 


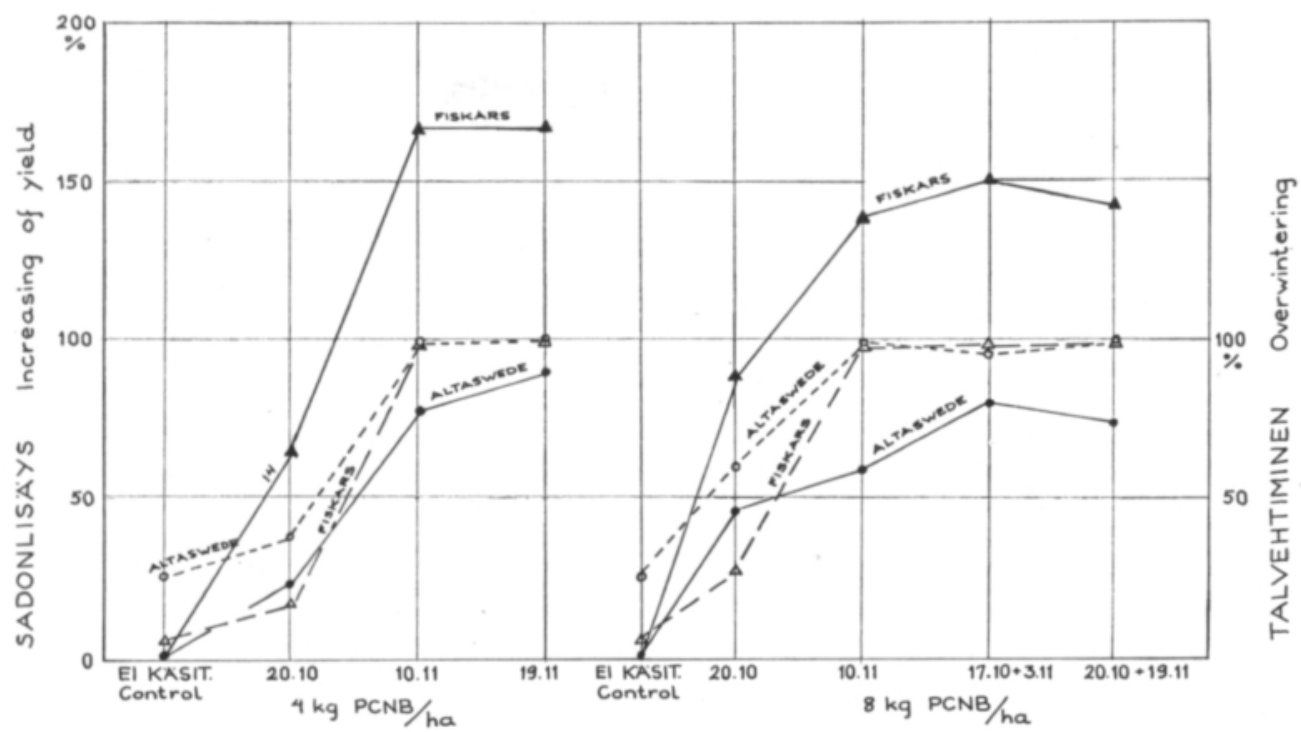

Kuva 7. Talvehtiminen ja sadonlisäykset käsittelyaika-ainemääräkokeessa Altaswede ja Tammiston puna-apilalla; katkoviiva $=$ talvehtiminen, yhtenäinen viiva $=$ sadonlisäys.

Fig. 7. Overwintering and increase of yields in experiments on time and amount of treatment in Altaswede and Tammisto red clover; broken lines $=$ overwintering, unbroken lines $=$ increase in yield.

Kun apilamädän leviäminen ja kasveihin iskeytyminen tapahtuu pääasiassa kasvillisuuskerroksen alla, on tärkeätä saada torjunta-aine tunkeutumaan sen läpi maan pinnalle. Tällöin pidättyy kasvien lehdille siksi suuri fungisidimäärä, että se riittää suojaamaan kasvit saastunnalta.

Suurin osa torjuntakokeista on suoritettu ensimmäisen vuoden nurmissa, koska niissä apilamädän tuhot ovat pahimmat. Apilamädän torjunta PCNB-valmisteilla onkin tuloksellisinta nurmen perustamisvuoden syksyllä suoritettuna. Joissakin kokeissa on seurattu ensimmäisenä syksynä suoritetun PCNB-käsittelyn vaikutusta nurmen satoon seuraavina vuosina (taul. 7). Käsittelyn jälkivaikutusta oli havaittavissa, jopa muutamissa tapauksissa hyvinkin voimakasta. Näissä kokeissa tuli esiin myös apilamädän torjunnan välillinen vaikutus, rikkaruohottumisen estyminen, jolla nimenomaan apilan siemenviljelyksillä on suuri merkitys.

Apilamädän PCNB-torjuntamenetelmää on käytetty menestyksellä hyväksi myös talvehtimiseen haitallisesti vaikuttavien bioottisten ja abioottisten komponenttien toisistaan erottamiseen siten, että ruutujen toinen puoli on käsitelty syksyllä PCNB-valmisteella (kuva 8). Eräiden tällaisten kokeiden tuloksia on taulukoissa 8-10. Niistä tulee ilmi apilamädän talvehtimista heikentävä merkitys yleensä ja myös lajikkeiden erilainen alttius taudille (vrt. Bengtsson 1961). Apilamätäepidemian voimakkuudesta riippuen on tässäkin suhteessa runsaasti vuosittaista vaihtelua, mutta suhteelliset kestävyyserot tulevat kuitenkin esiin. Taulukosta 9 voidaan havaita, että tetraploidiset apilat ovat olleet apilamätään nähden kestävämpiä kuin diploidiset. Useimmat prof. V.G r a s s o n Italiasta lähettämät apilat ovat menehtyneet talvemme ankarien sääolojen vuoksi. 


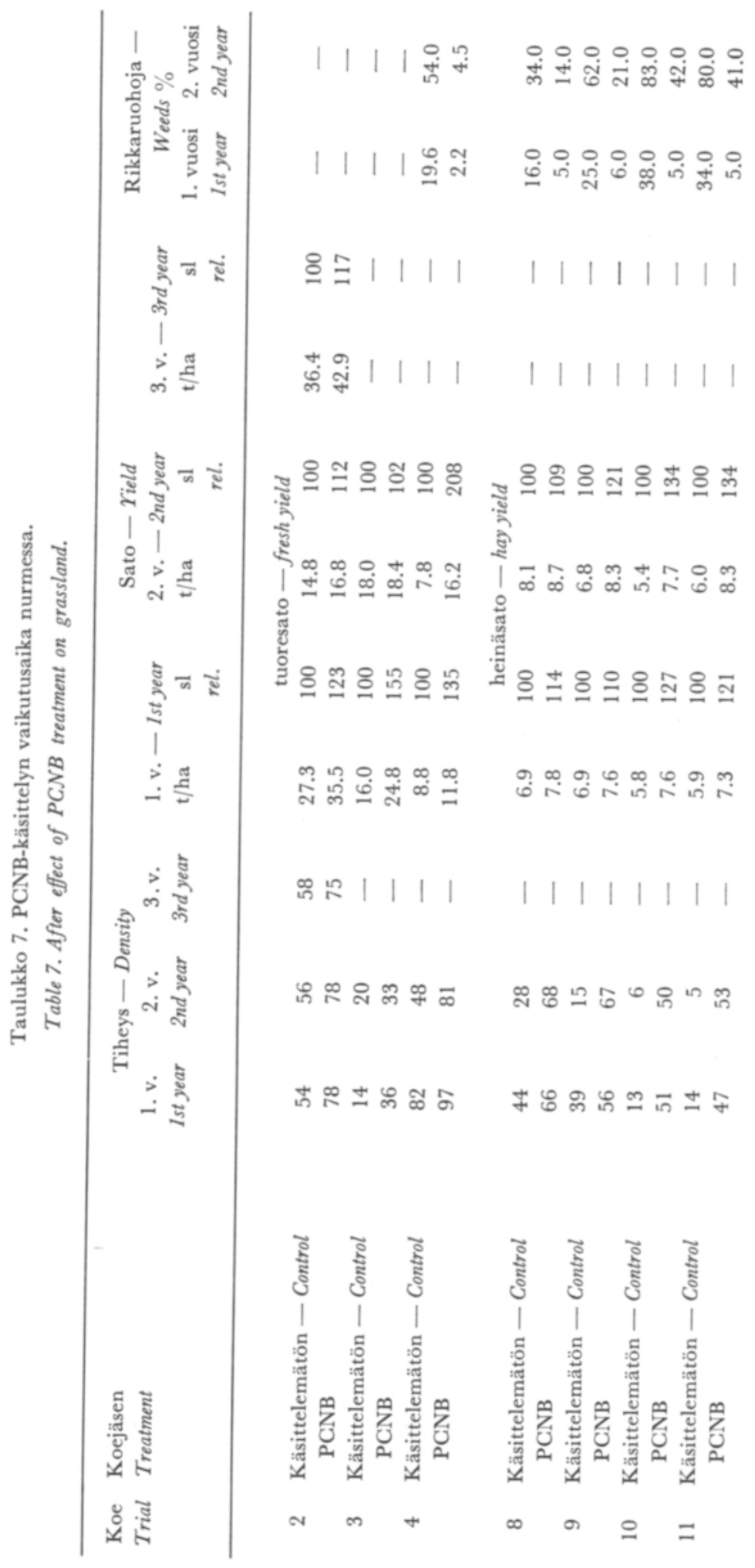




\section{Tiivistelmä}

Apilamädän levinneisyydestä ja vahingollisuudesta on kerätty aineistoa vuosina 19461965 eri tahoille maatamme tehdyillä matkoilla sekä kirjeellisillä tiedusteluilla. Kaikkiaan 91 kunnan alueelta (kuva 3) on kerätty ja puhtaaksi viljelty yhteensä 392 apilan pahkahomenäytettä. Aineisto osoittaa, että sieni on levinnyt kaikkialle apilan tärkeimmälle viljelyalueella. Muistiinpanot apilan talvehtimisesta sekä säähavainnot 20 vuoden ajalta Tikkurilassa (taulukot 1 ja 2) osoittavat, että apilamätäepidemian puhkeaminen on ensi sijaisesti riippuvainen syyskauden sääoloista ja lähinnä kasvillisuuskerroksessa vallitsevasta kosteudesta. Lämpötilan suoranainen merkitys on ilmeisesti vähäisempi. Pakkaset kuitenkin pysähdyttävät epidemian, koska silloin ilman suhteellinen kosteus laskee sienen kannalta

Taulukko 8. Apiloiden apilamädänkestävyyden testauksia PCNB:tä hyväksi käyttäen talvella 1958/59 Tikkurilassa.

Table 8. Testing of clovers against clover rot with PCNB in the winter 1958/59 in Tikkurila.

\begin{tabular}{lclc}
\hline $\begin{array}{l}\text { Apilalaji ja -lajike } \\
\text { Clover species and variety }\end{array}$ & $\begin{array}{c}\text { Talvehtiminen \% } \\
\text { Overwintering }\end{array}$ & $\begin{array}{c}\text { Apilalaji ja -lajike } \\
\text { Clover species and variety }\end{array}$ & $\begin{array}{c}\text { Talvehtiminen \% } \\
\text { Overwintering } \\
\text { Ei käsit. PCNBit. } \\
\text { Control }\end{array}$ \\
& & & $\begin{array}{c}\text { PCNB } \\
\text { Control }\end{array}$ \\
\hline
\end{tabular}

\begin{tabular}{|c|c|c|c|c|c|}
\hline \multicolumn{6}{|c|}{ Puna-apila - Red clover } \\
\hline Tammisto & 40 & 92 & Kosken tehdas & 65 & 65 \\
\hline Tenhola & 20 & 85 & Fiskars & 63 & 83 \\
\hline Hersnap tetr. & 25 & 95 & Kotim. k-erä & 55 & 85 \\
\hline Resistenta & 10 & 80 & Jokioinen & 80 & 95 \\
\hline Lindeberg & 60 & 80 & Tepa & 75 & 95 \\
\hline Arojärvi & 30 & 75 & Jokioinen, maat & 50 & 95 \\
\hline Hiekka & 75 & 90 & Laurila & 55 & 85 \\
\hline Vikkilä & 60 & 80 & Eerola & 75 & 90 \\
\hline Mäkinen & 60 & 85 & Perttola & 70 & 90 \\
\hline Hautahuhta & 65 & 90 & Ylitalo & 60 & 85 \\
\hline Ruots. k-erä & 50 & 85 & Resistenta & 5 & 75 \\
\hline Altaswede-52 & 60 & 85 & Alsikeapila $-A l$ & & \\
\hline Altaswede-57 & 25 & 65 & Tammisto & 65 & 80 \\
\hline Jutila & 65 & 80 & Weib. tetra & 65 & 90 \\
\hline Laatta & 80 & 95 & Jo TAal & 75 & 80 \\
\hline Leppäniemi & 30 & 60 & Alon & 5 & 75 \\
\hline Ypyä & 70 & 85 & Sinimailanen - & & \\
\hline Tasanko & 65 & 80 & Grimm & 65 & 85 \\
\hline Hirtolahti & 60 & 75 & Flamande & 65 & 80 \\
\hline Porola & 55 & 90 & Ferex & 70 & 95 \\
\hline Yli-Mutka & 70 & 80 & Kauppaerä I & 55 & 80 \\
\hline Pukkinen & 50 & 75 &,$\quad$ II & 60 & 85 \\
\hline Heikkilä & 45 & 65 & Jokioinen & 5 & 95 \\
\hline Ylikesti & 65 & 90 & Valkoapila $-W$ & & \\
\hline Ekerö & 65 & 80 & Tammisto & 60 & 95 \\
\hline Vierelä & 70 & 90 & Morsø & 60 & 75 \\
\hline Kullogård & 50 & 70 & Daeno II & 30 & 80 \\
\hline Hiidenoja & 60 & 70 & Ladino & 1 & 75 \\
\hline Kuuri-Riutta & 60 & 80 & & & \\
\hline
\end{tabular}


Taulukko 9. Puna-apiloiden apilamädänkestävyyden testaus PCNB:tä hyväksi käyttäen talvella 1960/61 Tikkurilassa.

Table 9. Testing of red clover against clover rot with PCNB in the winter 1960/61 in Tikkurila.

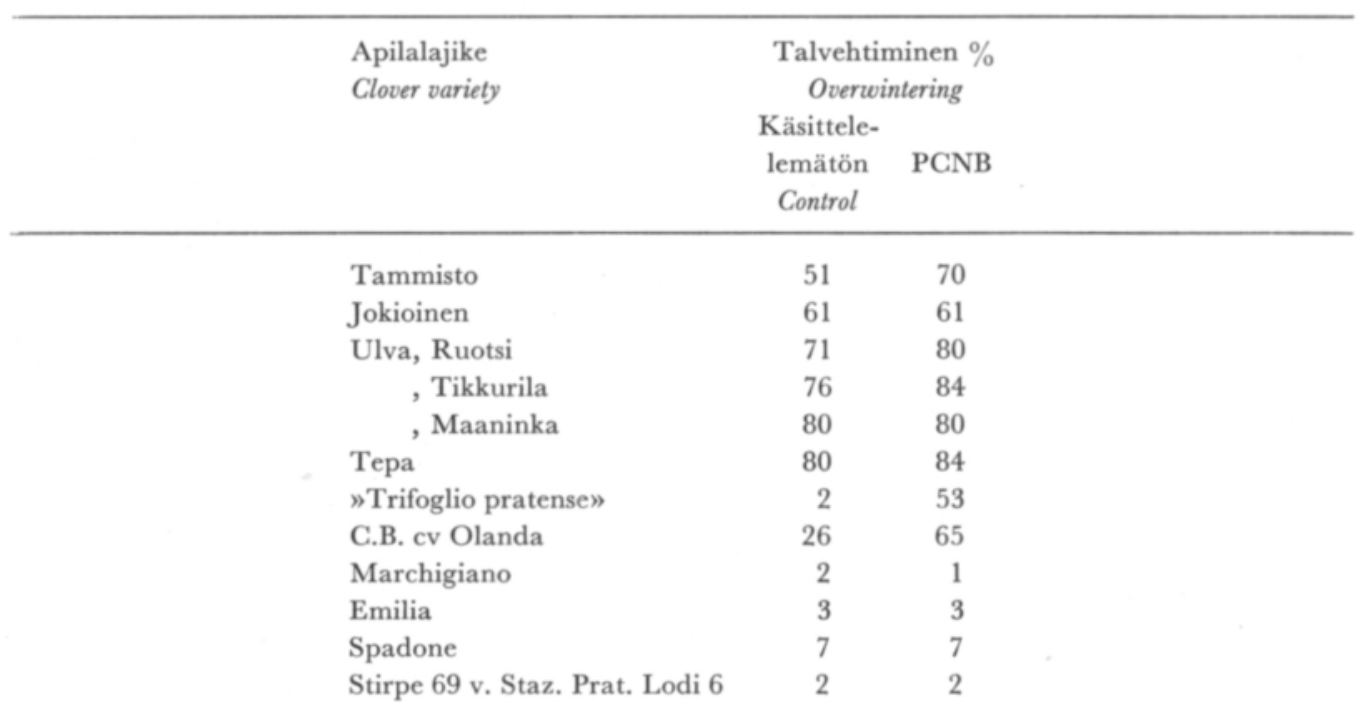

Taulukko 10. Puna-apilalajikkeiden apilamädänkestävyyden testaus 1961/62 Tikkurilassa.

Table 10. Testing of red clover varieties against clover rot with PCNB in the winter 1960/61 in Tikkurila.

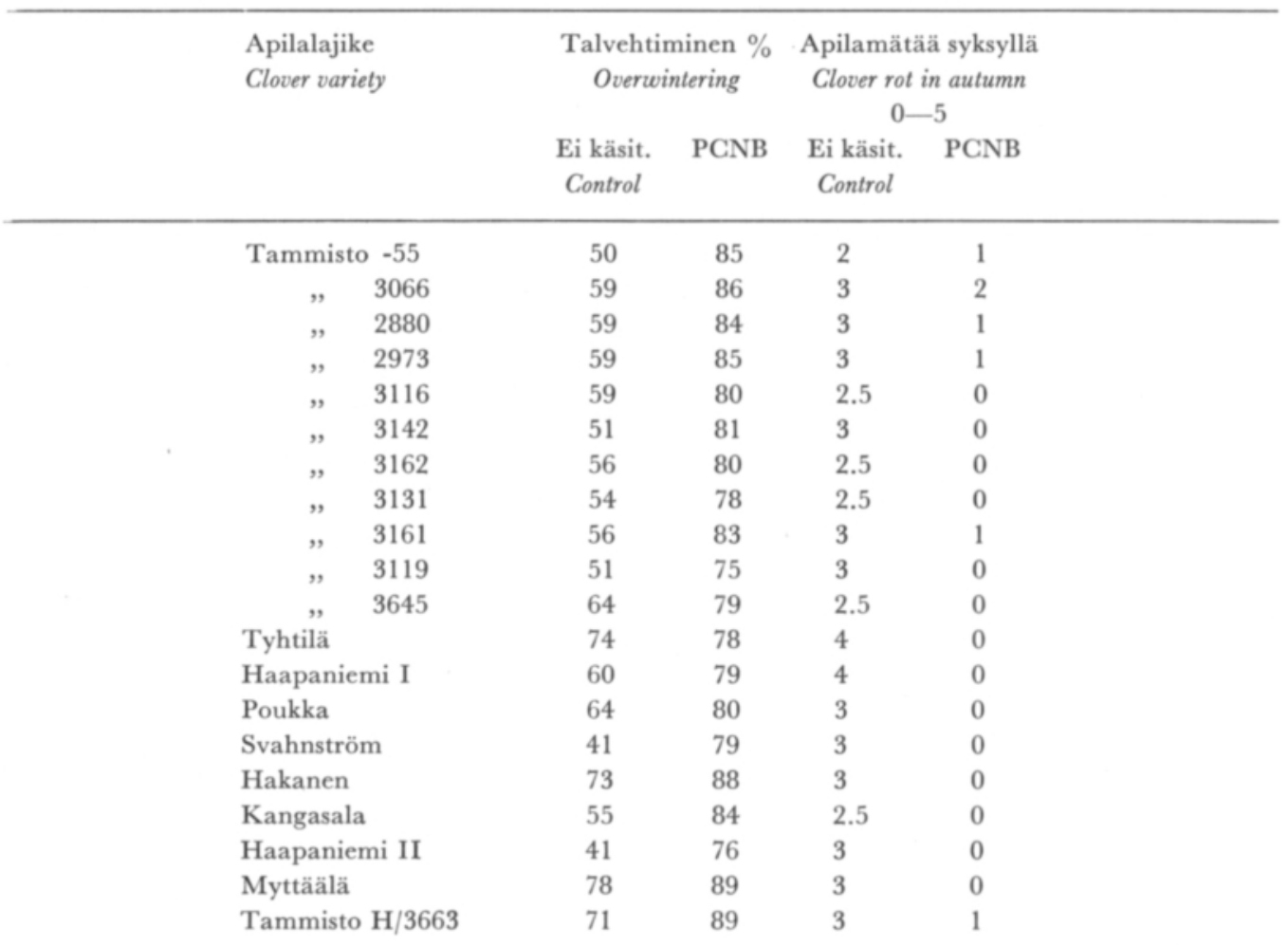




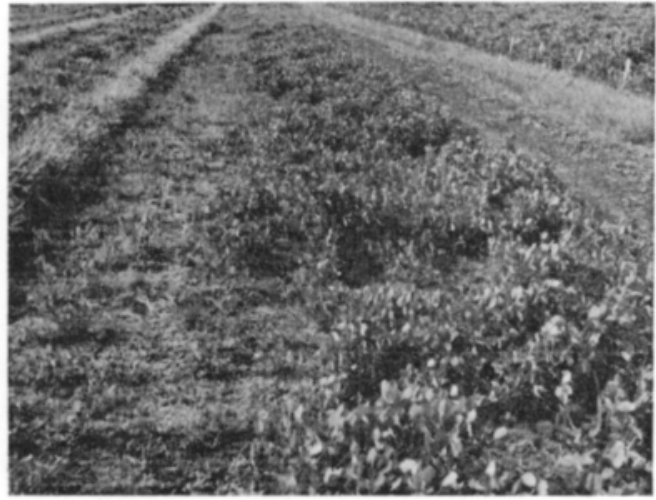

$\mathrm{O}$
PCNB
Kuva 8. PCNB:n vaikutus puna-apilan lajikekokeessa.

Fig. 8. Effect of $P C N B$ in variety trials of red clover.

liian alhaiseksi. Pitkinä, verraten leutoina syksyinä apilamädän tuhot voivat muodostua huomattavan suuriksi, niinkuin torjuntakokeet osoittavat.

Apilan pahkahomesienen on havaittu pellolla leviävän ja iskeytyvän apiloihin vielä $0^{\circ} \mathrm{C}$ :n lämpötilassa, joka on paljon alapuolella sienen rihmaston kasvun optimilämpötilan. Kotelomaljoja näyttää kehittyvän myös hyvin laajalla lämpötila-alueella, pakkasta ne eivät kumminkaan siedä. Runsaan lumipeitteen hidas sulaminen keväällä lisää maan pinnan kosteutta ja edistää apilamätätuhojen jatkumista vielä keväällä.

Muutamien eri alkuperää olleiden pahkahome-isolaattien patogeenisuudessa oli siksi merkitseviä eroja, että niitä voidaan pitää sienen eri biotyyppeinä. Toisaalta sekä eri isolaattien patogeenisuus että apilalajikkeiden taudinalttius näyttävät olevan suuressa määrin ajan funktioita (kuvat 4 ja 5). Apilalajikkeiden taudinkestävyyserot perustuvat niiden kykyyn viivyttää taudin valtaan pääsyä, eivät todelliseen resistenssiin. Maassamme on runsaasti pitkäaikaisen sopeutumisen tuloksena syntyneitä paikallisia puna-apiloita, jotka saattavat olla jalostusaineistona arvokkaita.

Vuosina 1946-1965 on suoritettu joukko apilamädän torjuntakokeita PCNB- eli kvintotseeni- valmisteilla eri tahoilla maata. Kun apilamädän esiintymisrunsaus vuosittain ja paikkakunnittain vaihtelee paljon, ja kun toisaalta torjuntakäsittelyjä on suoritettu monin erilaisin tavoin, ovat torjuntakokeiden tuloksetkin vaihtelevia. Kahdesti niitettäessä saatiin kaikista 145 käsittelystä keskimäärin tuoretta satoa lisää $41 \%$. Yhden kerran niitettäessä oli kuivan heinän lisäys 186 käsittelystä keskimäärin $26 \%$ (taulukko 4). Kaikista käsittelyistä on lähes puolet tuottanut kahdella niittokerralla vähintään $21 \%$ suuruisen tuoreen sadon lisäyksen ja yhdellä niittokerralla vajaa neljännes vähintään $21 \%$ suuruisen kuivaheinäsadon lisäyksen (taulukko 5).

Torjunnan onnistuminen riippuu ratkaisevasti sen aloittamisen ajankohdasta; torjunta on aloitettava ennen kuin apilamätä pääsee valtaan. Kun taudin puhkeaminen ja leviäminen voivat tapahtua vain kasvillisuuskerroksen ilmaston suhteellisen kosteuden ollessa hyvin korkea, lähes $100 \%$, on torjunnan ajankohta valittava syyskauden kosteusoloja seuraten. Joskus alkusyksyn oltua vähäsateinen on kokeissa riittänyt yksikin loka-marraskuussa suoritettu torjuntakäsittely, mutta varmempi tulos on saavutettu kahdella tai kolmella käsittelyllä syksyn aikana.

Käytännössä on ilmeisesti tarkoituksenmukaista suorittaa ensimmäinen torjuntakäsittely syys-lokakuun vaihteessa jos alkusvksy on sateinen ja toistaa käsittely noin kuukauden 
kuluttua. Jos alkusyksy on kuiva, suoritetaan vain yksi käsittely loka-marraskuun vaihteen tienoilla.

Riittäväksi tehoainemääräksi $(\mathrm{PCNB})$ on osoittautunut $5-6 \mathrm{~kg} / \mathrm{ha}$. Aineen määrän lisääminen tästä voi toisinaan antaa täydellisemmän torjuntatuloksen, mutta ero on siksi vähäinen, ettei se useimmiten vastaa kustannusten lisäystä. Ruiskutteilla on usein saatu paremmat tulokset kuin pölytteillä, joka on johtunut siitä, että ruiskutteiden tasainen levitys on helpompaa kuin pölytteiden, muuten ei käyttömuodolla ole ollut merkitystä.

Kun apilamädän tuhot yleensä ovat suurimmat ensimmäisen vuoden nurmissa, on niissä saatu myös parhaat torjuntatulokset. Kokeissa on todettu käsittelyllä olevan myös jälkivaikutusta seuraavina vuosina (taulukko 7). Edelleen voitiin havaita torjunnan välillisesti ehkäisevän nurmen rikkaruohottumista, jolla nimenomaan apilan siemenviljelyksillä on huomattava merkitys.

PCNB-torjuntamenetelmää voidaan käyttää hyväksi apilan lajike- ja muissa kokeissa apilamädän ja muiden talvehtimista heikentävien tekijöiden toisistaan erottamiseen (taulukot 8-10, kuva 8).

Kasvitautien tutkimuslaitoksen puolesta lausutaan kiitokset kaikille koeasemien ja muiden koepaikkojen toimihenkilöille, jotka ovat myötävaikuttaneet näiden kokeiden suorittamiseen, samoin kuin professori Vincenzo G r a s s o'lle, Bari, Italia, hänen ystävällisesti kokeiltaviksi toimittamistaan apilan siemenistä.

\section{KIRJALLISUUTTA}

Behringer, P. 1963. Ein Beitrag zur Sicherheit des Rotklee-Anbaues, insbesondere durch Bekämpfung des Kleekrebses (Sclerotinia trifoliorum Erikss.) Bayer. Landw. J. 40: 641:670.

Bengtsson, A. 1961. Klöverrötan och dess motverkande. Resultat från försök i Mellansverige. Summary: Clover rot and its control. Results from trials in middle Sweden. Kungl. Lantbr.-högsk. och Stat. Lantbr.-förs. Särtr. och Småskr. 155: 1-12.

BıNGefors, S. 1951. Sambandet mellan väderleksförhållandena och omfattningen av klöverrötangreppen vid Ultuna under åren 1930-1950. Sver. Utsädesför. Tidskr. 61: 100-107.

BJörLING, K. 1951. Uber die Entwicklungsgeschichte, Variabilität und Pathogenität von Sclerotinia trifolionum Erikss. Phytopath. Z. 18: 129-156.

CArr, A. J. H. 1954. Breeding red clover for resistance to clover rot disease. Repr. Rep. and Comm. Eight Int. Bot. Congr. Paris 1954, 18-20: 155-157.

ERIKsson, J. 1880. Om Klöfverrötan, med särskilt afseende på dess uppträdande i vårt land åren 1878 1879. Kungl. Landbr.-Akad. Handl. och Tidsskr. 1880: 28-42.

Frandsen, K. J. 1946. Studier over Sclerotinia trifoliorum Eriksson. 220 s., København.

Halkilahti, A-M. 1962. The survival of sclerotia of Sclerotinia trifoliorum Erikss. on the soil and the occurrence of clover rot in various years. Selostus: Sclerotinia trifoliorum Erikss. - sklerootionden säilyminen maassa ja apilamädän esiintyminen eri vuosina. J. Sci. Agric. Soc. Finl. 34: 154 -161 .

- - 1964. The significance of soil microorganisms as a limiting factor in infection of clover by Sclerotinia trifoliorum Erikss. at different times of the year. Selostus: Maan pieneliöstön merkityksestä apilan Sclerotinia trifoliorum Erikss. infektiota rajoittavana tekijänä vuoden eri aikoina. Ibid. 36: $120-134$.

Jamalainen, E. A. 1958. Peltokasvien huonon talvehtimisen syistä ja talvituhosienien aiheuttamien vahinkojen torjuntatoimenpiteistä. Summary: On reasons for poor overwintering of field crops and control measures against damage caused by low-temperature parasitic fungi. Maatal. ja koetoim. 12: 55-63. 
Krettlow, K. W. \& Spraque, V. G. 1951. Effect of temperature on growth and pathogenicity of Sclerotinia trifoliorum. Phytopath. 41: 752-757.

KöYlı̈̈̈rvı, J. 1959. Nurmen lannoituksesta ja apilan menestymisestä Pohjois-Suomen multa- ja turvemailla. Summary: The effect of fertilization upon red clover on humus and peat soils in northern Finland. Maatal. ja koetoim. 13: 139-148.

LEACH, C. M. 1958. Additional evidence for seed-borne mycelium of Sclerotinia sclerotiorum associated with clover seed. Phytopath. 48: 388-389.

Loveless, A. R. 1951. Observations on the biology of Clover rot. Ann. Appl. Biol. 38: 642-664.

Malmus, N. 1957. Zur Frage der Verhütung der Auswinterung durch Kleekrebs. Pfl.schutz 9: $107-109$.

Mukula, J., Marttila, M. \& Raatikainen, T. 1968. Heinänurmien sato vuosina 1966-68. Koetoim. ja käyt. 25: 45, 48.

PAPE, H. 1937. Beiträge zur Biologie und Bekämpfung des Kleekrebses (Sclerotinia trifoliorum Erikss.) Arb. Biol. Reichsanst. 22: 159-247.

Poнjakallio, O. 1939. Untersuchungen über den Kleekrebs und seinen Anteil am Verschwinden des Klees in Kleegrasgemischen. Pfl.bau 16: 136-160, 201-205.

—» 1940. Kasvinjalostusbiologisia tutkimuksia apilamädästä. S. Tiedeakat. Esit. ja Pöytäk. 1939: $115-128$.

— - 1959. Untersuchungen über Antagonisten der Erreger von Pflanzenkrankheiten. 4. Int. Pfl.schutz Kongr. Hamburg 1957: 211.

—- \& SAlonen, A. 1959. Puna-apilan viljelyn mahdollisuuksista Taka-Lapissa. Summary: On the possibilities of cultivation of red clover in Northermost Lapland. Maatal. ja koetoim. 13: 179186.

RöED, H. 1954. Mitrula sclerotiorum Rostr. and its relation to Sclerotinia trifoliorum Erikss. Acta Agric. Scand. 4: $78-84$.

Salminen, M. 1950. Eräitä Pohjois-Savon kasvinviljelyskoeaseman 20-vuotistaipaleelta saatuja koetuloksia ja kokemuksia. Koetoim. ja käyt. 1950, 3: 1.

Tertrinen, P. 1959. Apilanurmen niittoaikakokeitten tuloksia. Summary: Results of mowing-time trials on red clover ley. Maatal. ja Koetoim. 13: 208-217.

VAlle, O. 1935. Tuloksia vertailevista laatukokeista Tammistossa 1930-1934. Nurmikasvit. Hankkijan kasvinjal.laitos Tammisto. Siemenjulk. 1935: 67-89.

Valleau, W. D., Fergus, E. N. \& Henson, L. 1933. Resistance of red clovers to Sclerotinia trifoliorum Erikss. and infection studies. Ky. Agric. Exp. Sta. Bull. 341: 115-131.

YLIMÄKI, A. 1955. On the effectiveness of penta- and tetrachloronitrobenzenes on clover rot (Sclerotinia trifoliorum Erikss.) Selostus: Penta- ja tetrakloorinitrobenseenivalmisteiden tehosta apilamätään (Sclerotinia trifoliorum Erikss.). Acta Agric. Fenn. 83: 147-158.

- - 1956. Additional experiments on the chemical control of clover rot. Selostus: Lisäkokemuksia apilamädän torjumisesta kemiallisilla aineilla. Valt. Maatal.koetoim. Julk. 148: 31—49.

- - 1962. The effect of snow cover on temperature conditions in the soil and overwintering of field crops. Selostus: Lumipeitteen vaikutus maan lämpöoloihin ja peltokasviemme talvehtimiseen. Ann. Agric. Fenn. 1: 192-216.

- - 1967. Root rot as a cause of red clover decline in leys in Finland. Selostus: Juurilaho puna-apilan hävittäjänä Suomen niittonurmissa. Ibid. 6, Suppl. 1: 1-59.

- - 1968. Mitrula sclerotiorum Rostr., a parasite on the sclerotia of Sclerotinia trifoliorum Erikss. Selostus: Mitrula sclerotiorum Rostr. loisii Sclerotinia trifoliorum Erikss. pahkoilla. Ibid. 7: 105-106.

— — 1969 a. Typhula blight of clovers. Selostus: Apiloiden Typhula tauti Ibid. 8: 30-37.

- - 1969 b. The effect of some chemicals on the fungus Sclerotinia trifoliorum Erikss. Selostus: Eräiden kemikaalien vaikutus Sclerotinia trifoliorum sieneen. 41 J. Sci. Agric. Soc. Finl. 41.

ZogG, H. 1957. Versuche zur chemischen Bekämpfung des Kleekrebses (Sclerotinia trifoliorum). Mitt. Schw. Landw. 5: 165-172.

ZuB, J. 1967. Grzyb Mitrula sclerotiorum Rostr. w Polsce oraz próky okreslenia jego stosunku biologicznego do patogena raka koniczynowego (Sclerotinia trifoliorum Erikss.). [M. sclerotiorum in Poland and attempts to determine its relation to the pathogen of clover rot (S. trifoliorum) ]. Pr. Nauk. Inst. Ochr. Rosl. 9,1: 15-40. 


\title{
S U M M A R Y
}

\section{CLOVER ROT AS A CAUSE OF POOR OVERWINTERING OF CLOVER IN FINLAND}

\author{
AARre YlimäKI \\ Department of Plant Pathology, Agricultural Research Centre, Tikkurila, Finland
}

Material on the distribution and damage of clover rot was collected in the years 1946-1965 during journeys in different parts of the country and through inquiries made by letter. A total of 392 Sclerotinia trifoliorum samples from an area of 91 communes (Figure 3) were collected and cultivated. The material indicates that the fungus is spread over all the most important areas of red clover cultivation. Notes on the overwintering of cultivated plants and meteorological observations during 20 years in Tikkurila (Tables 1 and 2) show that the occurrence of clover rot epidemies mainly depends on the climatic conditions of the autumn and on the humidity of the vegetation layer. The direct significance of the temperature is evidently smaller, cold however stops the epidemic, as the relative humidity of the air becomes too low for the fungus. During a long, rather mild autumn, the damage caused by clover rot can be considerable as is indicated by the control trials.

It has been observed that clover rot spreads and attacks clover plants even at a temperature of $0^{\circ} \mathrm{C}$ which is far below the optimum temperature of the growth of the mycelium of the fungus. Apothecia seem likewise to develop in a wide temperature range, though they do not tolerate frost. The slow melting of the snow in spring increases the humidity on the surface of the soil and promotes the damage by clover rot.

The differences in the isolates of $S$. trifoliorum in regard to their pathogenicity were so significant that they can be considered as being different biotypes of the fungus. On the other hand the pathogenicity of different isolates and the susceptibility of the different clover varieties to disease seem to a great extent to be the functions of time (Fig. 4 and 5). The differences in clover varieties in their resistance to disease, are thus based on their ability to delay the domination of the disease rather than on real resistance. In Finland there are many local red clovers which are a result of long-term adaption and may prove valuable as breeding material.

A number of clover rot control experiments with PCNB or quintozene - preparations were carried out on grasslands in different parts of the country in the years 1946-1965. Because the abundance of clover rot varies, both annually and locally and because control treatments have been carried out in many different ways, the results of the control experiments also vary. With two mowings the increase of the fresh yield of all the 145 treatments was approx. $41 \%$. With one mowing the increase of dry hay in 186 treatments was approx. $26 \%$ (Table 4). Of all the treatments about one half has given an increase of fresh yield of not below $21 \%$ after two mowings and nearly a quarter of an increase in the dry hay yield amounting not less than $21 \%$ after one mowing (Table 5).

The success of the control depends decisively on the time it is started. The control should start before the clover rot has become dominant. Because the outbreak and spread of the disease takes place only when the relative humidity in the vegetation layer is very high, the time chosen for the control should be based on the conditions of humidity in the autumn. When the early autumn has been less rainy, only one control treatment has been sufficient in October-November, even if a more certain result is obtained with $2-3$ treatments during the autumn. In practice it is evidently appropriate to carry out the first control treatment at the end of September - the beginning of October if the autumn is rainy, and to repeat it after about one month. If the early part of the autumn is dry, only one treatment is needed approximately at the end of October - early November.

$5-6 \mathrm{~kg} / \mathrm{ha}$ has proved to be a sufficient amount of effective substance (PCNB). Additional substance may sometimes give a more complete control result, but the difference is so small that it does not always equal the extra cost involved. Better results have been obtained with sprays than with dusts owing to the fact that it is easier to apply sprays than dusts evenly, apart from that the forms of usage have not been significant.

Because the damage of clover rot is generally greatest in first year leys, they have also yielded the best control results. In these experiments it has been established that the treatment has also aftereffects in the following years (Table 7). It appears that the control has indirectly prevented the weeding of grasslands, which especially on clover seed cultivations is of major significance.

The control method with PCNB may be used e.g. in variety and other trials of clover to distinguish clover rot from other factors lowering the overwintering (Tables 8-10, Fig. 8). 